\title{
Water Consumption Pattern among Young Adults in a Higher Institution in Mubi Adamawa State
}

\author{
Nkereuwem Sunday Etukudoh1, Ocheola Oki Joyce Ene ${ }^{2 *}$ \\ ${ }^{1}$ Department of Haematology, Federal School of Medical Laboratory Science, Jos, Plateau State, Nigeria \\ ${ }^{2}$ Federal School of Medical Laboratory Science, Jos, Plateau State, Nigeria \\ Email: uwemetuklab@yahoo.com, *katejoshua@yahoo.com
}

How to cite this paper: Etukudoh, N.S. and Ene, O.O.J. (2020) Water Consumption Pattern among Young Adults in a Higher Institution in Mubi Adamawa State. Food and Nutrition Sciences, 11, 969-982. https://doi.org/10.4236/fns.2020.1110068

Received: September 3, 2020

Accepted: October 26, 2020

Published: October 29, 2020

Copyright $\odot 2020$ by author(s) and Scientific Research Publishing Inc. This work is licensed under the Creative Commons Attribution International License (CC BY 4.0).

http://creativecommons.org/licenses/by/4.0/ (c) (i) Open Access

\begin{abstract}
Considering the injurious effects of hypohydration, a study on the water consumption pattern of young adult in a specified higher institution in Adamawa State was sought due to concerns on the low plain water consumption with the objectives of understanding the average daily consumption, as well as knowing contributors to total body fluid intake. A qualitative cross sectional sweep survey (CSSS) using simple random sampling (SRS) method was carried out, a pilot sturdy which achieved a cronback alpha of $>0.7$ reliability questionnaire was used to carry, while Conchrans formula was adopted to determine sample size $\mathrm{N}$, which was 400 . The result showed that majority of the respondents 176(44) were 21 years of age in their early adulthood, many, 187(46.75) used borehole water as their source of household water. Most of the respondents $272(69)$ agreed to drinking rain water. Some respondents 200(50) choose pure satchet water as their major source of drinking water, about half 200(50) of the respondents drink $1.5 \mathrm{~L}$ or less of water daily, while only 13(3.25) of the respondents drink 5 - $6 \mathrm{~L} /$ day of water, on the average. Most of the respondents 174(43.3) take orange as their most commonly consumed fruit, taking a maximum of 4 oranges per day, 160(40) of the respondents eat apple as their most commonly consumed fruit, with a maximum of one apple a day both apples and oranges give $87 \%$ fluid of their total weight. Some respondents 40(10) attested to being diabetic, with 13(3.26) of them agreeing to consuming alcohol, 377(94.25) confirmed they drink at least a bottle of carbonated drink daily. The study reveals that most young adults (21 - 25 years of age) in the sturdy area drink below the recommended daily requirement for water therefore, intervention as well as public enlightenment is required to encourage good water consumption pattern among young adults.
\end{abstract}


Keywords

Water, Consumption Pattern, Young Adults, Hypohydration

\section{Introduction}

In the most developed world, drinking water is commonly linked with low health concern [1] [2]. There is evidence backing the fact that Water is possibly the most fundamental nutrient of all, as poor intake is usually lethal within just a few days [3]. Water is known to be essential for all bodily functions, including nerve conduction, temperature regulation and many chemical reactions. Instabilities in hydration status have the tendencies to bring about changes in tissue osmolality and in cell volume, leading to known changes in cell and tissue function [4]. The primary regulated variables are the osmolality and volume of the vascular space, though the distribution of water within the various body compartments is also tightly regulated. Euhydration (i.e. a normal state of hydration) is maintained primarily by control of both water input, i.e. intake and output, i.e. loss. Despite the fact that water is recognized as very important to the human body, there is paucity of data on the drinking water consumption patterns among young adults as well as details of other sources of fluid among young adults in Mubi, Adamawa State. Most dietary surveys do not take into consideration, or report total water intake, and hydration status of participants [5].

\section{Brief Review}

\section{Recommendations from various authorities}

For the reason that there are mounting evidence of both short- and long-term negative effects of hypo hydration on health and well-being [3], guidelines have been established to determine how much water humans require (on average) to circumvent dehydration and to optimize physical and psychological function such as "Daily Reference Values" (DRVs) or "Adequate Intakes" (AIs) range from $2 \mathrm{~L}$ /day for women and $2.5 \mathrm{~L} /$ day for men from the European Food Safety Authority [7], up to $2.7 \mathrm{~L} /$ day for women and $3.7 \mathrm{~L} /$ day for men from the Institute of Medicine [6] (Table 1). Most estimates of adequacy are based on mean or median intake of water from observational epidemiological studies of apparently healthy people [6], or intakes in combination with urine osmolarity [7]. They are at best a guideline against which to measure the fluid intake of populations, but the coefficient of variation or range of acceptable intakes is not well specified and individuals may require much more or much less than these values depending on the age range, apart from the fact that these values probably did not include data from African countries.

According to a study by [8], it was aimed at identifying and characterizing patterns of fluid intake in children and adolescents from six countries: Argentina, Brazil, China, Indonesia, Mexico and Uruguay, in the study, total of 
Table 1. Recommendations for total water intake from various authorities (L/day) for adults.

\begin{tabular}{|c|c|c|c|c|c|c|}
\hline & \multicolumn{2}{|c|}{ EFSA (2010) } & \multicolumn{2}{|c|}{ IOM (2005) } & \multicolumn{2}{|c|}{ WHO (2003) } \\
\hline & Male & female & Male & female & Male & female \\
\hline 19 - 50 years & 2.5 & 2.0 & 3.7 & 2.7 & 2.9 & 2.2 \\
\hline 51 and above & 2.5 & 2.0 & 3.7 & 2.7 & 2.9 & 2.2 \\
\hline Pregnancy & \multicolumn{2}{|c|}{2.3} & \multicolumn{2}{|c|}{3.0} & \multicolumn{2}{|c|}{4.8} \\
\hline Lactation & \multicolumn{2}{|c|}{2.7} & \multicolumn{2}{|c|}{3.8} & \multicolumn{2}{|c|}{5.5} \\
\hline
\end{tabular}

SOURCES: EFSA: European Food Safety Authority [6]; IOM: Institute of Medicine [7]; WHO: World Health Organization [8].

eight fluid types were used in this cluster analysis to spot fluid intake patterns in children and adolescents across six countries, but notably young adults were not specified, and no African country was included in this study. The first observation was that the FI patterns in this analysis were driven by Sugar Sweetened Beverage (SSB) and water as seen in Table 2, and to a lesser extent milk and its derivatives. Secondly, it seems that the most outstanding observation was that the most significant characteristic across the FI patterns was country of residence. The study found out that Latin American countries were more represented in the low drinkers-SSB or the high drinkers-SSB FI patterns showing that they have strong affinity to SSB as compared to water. These results are unswerving with reports based on volumes of fluid types consumed but with a little difference in what is seen in Table 2, where we have very high drinkers of water with the figures higher that those who drink SSB or milk derivatives, but with variations based on countries [9] [10]. The research also found that high intakes of SSB in Latin American countries have before now raised concerns according to some associations with dental caries [11], obesity and overweight [12] and associated metabolic conditions among children and adolescent. In adding up to high SSB intake, residence in Brazil, Mexico and Argentina were found to be associated with low total fluid intake (low drinkers-SSB). The mean Total Fluid Intake (TFI) for this cluster was $1 \mathrm{~L} /$ day, which compares adversely with recommendations on the Adequate Intake (AI) of water from fluids [13]. Researchers also posit that Children and adolescents in these countries may be at risk of suboptimal hydration, which is associated with impaired cognition and low mood [14] apart from poor physical performance [14]. On the other hand, Uruguayan children and adolescents had high TFI and were over-represented in the high drinkers-SSB pattern. Hence, interventions may be most successful if it is aimed at replacing energy-containing drinks with water while ensuring that the TFI is well maintained. Even though this analysis was not specific on young adults, it goes ahead to suggest that interventions in these countries should be targeted at increasing drinking water consumption while reducing sugar fluid intake. This can be achieved in some countries, including Mexico [15], by adopting the approach of introducing taxes which help to increase the price 
Table 2. The table of mean $( \pm S D)$ daily intake of water, total fluid intake, and percentage of daily water intake in $\mathrm{ml} /$ day within clusters in children and adolescents from $4-17$ years.

\begin{tabular}{|c|c|c|c|c|c|c|}
\hline & $\begin{array}{l}\text { High drinkers } \\
\text { of ssb } \\
n=513\end{array}$ & $\begin{array}{l}\text { Low drinkers } \\
\text { of ssb } \\
n=523\end{array}$ & $\begin{array}{l}\text { Low drinkers } \\
\text { water-milk } \\
\mathrm{n}=615\end{array}$ & $\begin{array}{l}\text { Medium } \\
\text { mixed } \\
\text { drinkers } \\
\mathrm{N}=914\end{array}$ & $\begin{array}{l}\text { High drinkers } \\
\text { of water } \\
\text { n = } 352\end{array}$ & $\begin{array}{l}\text { Very high } \\
\text { drinker of } \\
\text { water } \\
n=264\end{array}$ \\
\hline Water & $325-281^{d}$ & $209-152^{\mathrm{e}}$ & $332-166^{d}$ & $952-467$ & $1893-265^{b}$ & $2972-633^{a}$ \\
\hline TFI & $2028-739$ & $1000-431$ & $1076-420$ & $1681-552$ & $2654-642$ & $3411-771$ \\
\hline \%of WI & 16.02 & 20.9 & 30.85 & 56.63 & 71.32 & 87.12 \\
\hline
\end{tabular}

Excerpt from; European Journal of Nutrition (2018) 57 (Suppl 3): S113-S123

https://doi.org/10.1007/s00394-018-1725-y. ${ }^{*}$ The bold and italicized figures where predominant in each cluster. ${ }^{*} \mathrm{~A}$ one way ANOVA was performed with Tarkey Post Hoc test to identify the difference between clusters. Clusters not identified by same letters are significantly different $(\mathrm{p}<0.05)$. SSB = Sugar Sweetened Beverage; TFI $=$ Total Fluid Intake; WI $=$ Water Intake.

of sugar drinks; it is possible that this will particularly influence those in lower Socio Economic Levels (SELs) [16].

The analysis went further to show that Chinese residents were principally in the low drinkers-water and milk FI cluster (51\%); a pattern in which the younger children (4 - 9 years) were over-represented; this policy based pattern ensures that as children take lunch boxes to school, fluid is been made available for them at school, good as this may seem this policy did not take into consideration the food content as guide for the quantity of water provided and this may lead to over hydration if not properly checked. This pattern is the reflection of the policies implemented in China whereby a school lunch must includes a serving of $250 \mathrm{~mL}$ of milk and made available to first and middle-school children [17] [18] meaning the fluid inclusion is specific for milk and not water.

Interestingly, Indonesians were over-represented in both the high drinkersand very high drinkers-water patterns; these FI patterns have TFIs $>2.5 \mathrm{~L} /$ day as shown in a previous analysis [19]. From the present analysis, it would appear that in terms of fluid volume and type, there is little of concern that requires intervention in these latter two clusters. This could be due to all proactive actions undertaken in Indonesia to increase the access to safe water (WHO/UNICEF, 2017) [20] sand to encourage water consumption [21]. However, with increasing levels of obesity [22] and type 2 diabetes [23], in Indonesia there are concerns about increasing SSB consumption.

Fluid pattern analyses in children and adolescents have been conducted in the USA [24] and Canada [25], but not much reflected on young adults as an age group especially those from African descent.

In Nigeria especially the north eastern part, not much work has been done on young adult's water consumption pattern to clarify the hydration needs of the population as well as likely risk factors that could emerge as a result of under or over hydration. It is against this backdrop that this research carried out a sweep survey to understand the drinking water consumption pattern among young 
adults in Mubi Adamawa State, apart from getting to know other sources of their total body fluid intake.

The objectives of these studies are to 1) Understand the water consumption pattern of young adults in a specified higher institution in Mubi, Adamawa State in terms of average daily consumption, and 2) The studies also aimed at knowing major contributor to the total body fluid among young adults apart from knowing the impact of socio-economic status on their fluid intake.

\section{Methods}

Study Design: Cross Sectional Sweep Survey (CSSS), using a simple random sampling method (SRSM).

\section{Study Area}

Mubi metropolis as a geo-political area comprises of two local government areas; Mubi North and Mubi South. According to [26], the area is located between latitude $10^{\circ} 30^{\prime}$ and $10^{\circ} 05^{\prime}$ of the equator and between longitude $13^{\circ} 10^{\prime}$ and $13^{\circ} 30^{\prime} \mathrm{E}$ of the Greenwich meridian. It occupies a land area of $192.30 \mathrm{Km}$ and supports a total population of 260.009 people [27]. Mubi Township came into existence on the $1^{\text {st }}$ of April 1936. The growth of mubi can be traced to the agricultural, administrative and commercial functions it performs.

Bordered by neighboring tribes such as Fali, Gude, Kilba, Higgi, Margi, and Njanyi, it has the following higher institutions, Adamawa State University, Federal Polytechnic Mubi, and School of Health Technology Mubi.

A self administered questionnaire was adopted from [28] and modified to capture or, better reflect the drinking water consumption pattern of all the respondents. The questionnaire administered in July 2019, had two sections, the first section captured the demographic and socio-economic characteristics of the respondents, while the second section took into consideration questions pertaining to the water consumption/fluid consumption pattern of the respondents. A pilot study was carried out to assess the reliability of the modified questionnaire. A Cronback alpha of $>0.7$ was obtained for all sections which indicated a good reliability.

Two $24 \mathrm{hr}$ dietary recalls was carried out in two days of the week, one week day and one weekend just for water consumption. This helped to capture the source of drinking water and fluids consumed by the participants, of which an average of the two was calculated and used.

Inclusion Criteria: All the respondents were registered students of the selected higher institution, and schooling in the higher institution in Mubi Adamawa State and must be within the ages of 21 years - 25 years; these age groups are considered young adults in most publications even though there are conflicting recommendations on the age brackets for young adults.

Exclusion criteria: Young adults who are not students of the selected higher institution where not included as one other criteria was a valid identity card.

Sample Size Determination 
The Crochrans formula was used to determine the sample size being that the research is a survey and random sampling method was used with the assumption that at least half of the students maintained a healthy drinking water and fluid consumption pattern, even without being aware of it. As a result this formula was deemed suitable for the work.

\section{Equation 1.}

\section{Cochrans formula:}

$$
n_{0}=z^{2} p q / \mathrm{e}^{2}
$$

where $\mathbf{e}=$ the desired level $\mathrm{f}$ precision (i.e. margin of error)

$p=$ the estimated proportion of the population which has the attributes in question (good drinking water/fluid pattern)

And $\boldsymbol{q}=1-p$.

Assuming $\boldsymbol{p}$ is 0.5 at $95 \%$ confidence level.

The $z$-value $=1.96$

Therefore $n_{0}=(1.96)^{2}(05)^{2}(0.5)^{2} /(0.05)^{2}=385$

In other to make room for error in filling the questionnaire this value was adjusted to 410 respondents of which 400 respondents answered the questionnaire correctly and the 400 was used for this research.

\section{Results}

The water consumption pattern among young adults in a higher institution in Mubi Adamawa State was carried out and the results obtained were as follows;

\section{Discussion}

The result shows that equal number of participants, took part in terms of gender, 200(50) males and 200(50) females respectively, this was deliberate since the research design is cross sectional.

Enquiry from Table 3 which shows their socio-demographic or socio economic characteristics, on their marital status showed that $320(80)$ of the respondents where single, $48(12)$ were married, while $32(8)$ of the respondents were divorced, none was widowed or separated. This gives a reflection that child marriage is gradually being faced out in this part of the country as the result tends to contradict the works of [29] [30], in terms of the age of marriage, as well as works by [31], which worked specifically in the North eastern part of Nigeria, which shows that the mean age for marriage in this region was 15.8 years, but this wok shows an upward shift, even though there works were not based particularly on young adults and this could also be the result of better education.

The respondents whose ages ranged between 21 - 25 years, had 176(44) of the respondents who were 21 years old, 64(16) of the respondents where 22 years old, 32(8) of the respondents where 23 and 24 years of age respectively, while 96(24) of the respondents were 25 years of age. This result shows that the majority $176(44)$ of the young adults in this very institution were in the very early 
stage of their young adulthood, while the middle young adult were made up of few individuals 32(8) as seen in Table 3.

Table 3. Socio-demographic and economic characteristics of the respondents.

\begin{tabular}{|c|c|c|c|}
\hline$s / n$ & Questions & Quantity (n) & Percentage (\%) \\
\hline \multirow[t]{4}{*}{1.} & Gender of respondents & & \\
\hline & Male & 200 & 50 \\
\hline & Female & 200 & 50 \\
\hline & Transgender & 00 & 00 \\
\hline \multirow[t]{6}{*}{2.} & Marital status & & \\
\hline & Single & 320 & 80 \\
\hline & Married & 48 & 12 \\
\hline & Divorced & 32 & 08 \\
\hline & Widowed & 00 & 00 \\
\hline & Separated & 00 & 00 \\
\hline \multirow[t]{6}{*}{3.} & Respondents age & & \\
\hline & 21 & 176 & 44 \\
\hline & 22 & 64 & 16 \\
\hline & 23 & 32 & 08 \\
\hline & 24 & 32 & 08 \\
\hline & 25 & 96 & 24 \\
\hline
\end{tabular}

4. Estimated monthly income of respondents

\begin{tabular}{|c|c|}
\hline 丹5.000 - $\$ 9.999$ & 208 \\
\hline$\$ 10,000-\$ 14,999$ & 80 \\
\hline N15,000 - 19.999 & 00 \\
\hline$\approx 20,000-\approx 24,999$ & 16 \\
\hline Above $\approx 25,000$ & 96 \\
\hline
\end{tabular}

5. Respondents occupation

$\begin{array}{ccc}\text { Civil servant } & 80 & 20 \\ \text { Trader } & 00 & 00 \\ \text { Farmer } & 00 & 00 \\ \text { Artisan } & 00 & 00 \\ \text { Students } & 320 & 80 \\ \text { Others } & 00 & 00\end{array}$

6.

Educational qualification

$\begin{array}{ccc}\text { Higher institution } & 400 & 100 \\ \text { Postgraduate } & 00 & 00\end{array}$


On the estimated monthly income of the respondents, (which could either be what they work for or upkeep money they are given from home), 208(52) of the respondents earned between $\$ 5.000$ - $\$ 9.999$ naira monthly, while only 96(24) of the respondents earned above $\$ 25,000$ naira monthly, over half of the respondents survive on less that 10.000 naira monthly which is adversely very poor in this technological age, this is a reflection of the poverty that is ravaging the north eastern part of the country and a direct result of insurgency and high levels of insecurity in the region, and in the nation as a whole. This is further described by [32] from the theoretical perspective; he illustrated the family investment theory as the amount of money parent put into purchasing quality education, nutrition and health among other things to improve a Childs future wellbeing. This amount will in turn affect their water consumption pattern as well as the quantity and quality of the water and other fluid sources consumed. There is need for the government to put policies in place to support students in higher institutions in the region and Mubi in particular to promote education.

Questions on occupation showed that $80(20)$ of the respondents affirmed to being civil servant whose salary where above $\$ 25.000$, while 320 (80) of the respondents claimed not to work or engage in any form of entrepreneurial activities, but were full time students, showing that they depend totally on home front for sustenance, this is evidence to the fact that that most of the respondents are not skilled for entrepreneur or if skilled lack the finances to engage in it in order support their educational pursuit. Practical entrepreneur should be given priority in higher institutions with a close-mark monitoring. This also goes to shows that 16 of the 96 participant who earned above $\$ 25.000$ do not work, but probably come from homes with moderate socio-economic levels (SELs).

All of the respondents were students of the selected institution, but none of them was studying at postgraduate level.

On the source of household water of the respondents as seen in Table 4, majority of the respondents 187(46.75) used borehole water as their major source of household water, 67(16.75) used tap water as their household water source, 53(13.25) got their household water from private wells, while 40(10) of the respondents used public well water as their household water source. Other respondents 52(13) who participated in this research claimed they get their water from water vendors and do not ask them specifically the source, while only $1(0.25)$ of the respondent gets household water from stream as seen in Table 4, according to this respondent, the stream serves as a major source of water for people living around the community the respondent lives, showing that the student live off campus far from the reach of even water vendors most likely. The results in Table 4, also shows that the likelihood of water borne diseases may be minimal going by the fact that most of the respondents do not use open flowing water which could be contaminated by dung of grazing animals or human faeces since the area is well known for animal grazing, and may also have poor sewage management. Apart from this, according the Center for Disease Control and Prevention [33], the presence of contaminants in drinking water can lead to adverse 
Table 4. Water/fluid consumption pattern of the respondents.

\begin{tabular}{|c|c|c|c|}
\hline $\mathbf{s} / \mathbf{n}$ & Questions & Quantity (n) & Percentage (\%) \\
\hline \multirow[t]{7}{*}{1.} & Source of household water & & \\
\hline & Tap water & 67 & 16.75 \\
\hline & Borehole water & 187 & 46.75 \\
\hline & Public well & 40 & 10.00 \\
\hline & Private well & 53 & 13.25 \\
\hline & Streams or river & 1 & 0.25 \\
\hline & Others & 52 & 13.00 \\
\hline \multirow[t]{3}{*}{2.} & Drink rain water & & \\
\hline & Yes & 272 & 69 \\
\hline & No & 128 & 32 \\
\hline \multirow[t]{7}{*}{3.} & Most common drinking water source & & \\
\hline & Pure sachet water & 200 & 50.00 \\
\hline & Bottled water & 93 & 23.25 \\
\hline & Plain tap water & 13 & 3.25 \\
\hline & Well water & 53 & 13.25 \\
\hline & Stream or river & 01 & 0.25 \\
\hline & Borehole water & 40 & 10.00 \\
\hline \multirow[t]{7}{*}{4.} & $\begin{array}{l}\text { Approximate quantity of water consumed } \\
\text { mean per-day and equivalent in litres }\end{array}$ & & \\
\hline & 1 - 3 sachets $/ 0 \mathrm{~L}-1.5 \mathrm{~L}$ & 200 & 50.00 \\
\hline & $4-6$ sachets $/ 2 \mathrm{~L}-3 \mathrm{~L}$ & 107 & 26.75 \\
\hline & 7 - 9 sachets/3.5 L - $4.5 \mathrm{~L}$ & 80 & 20.00 \\
\hline & 10 - 12 sachets/5 L - $6 \mathrm{~L}$ & 13 & 3.25 \\
\hline & 13 - 15 sachets/6.5 L - $7.5 \mathrm{~L}$ & 00 & 0.00 \\
\hline & Above 15 sachets/>7.5 L & 00 & 0.00 \\
\hline \multirow[t]{6}{*}{5.} & Most common fruit type consumed & & \\
\hline & Orange & 174 & 43.50 \\
\hline & Apple & 160 & 40.00 \\
\hline & Water melon & 80 & 20.00 \\
\hline & Mango & 53 & 13.25 \\
\hline & Banana & 53 & 13.25 \\
\hline \multirow[t]{3}{*}{6.} & Have diabetes & & \\
\hline & Yes & 40 & 10.00 \\
\hline & No & 360 & 90.00 \\
\hline \multirow[t]{3}{*}{7.} & Take alcohol & & \\
\hline & Yes & 13 & 3.25 \\
\hline & No & 387 & 96.75 \\
\hline \multirow[t]{3}{*}{8.} & Take carbonated drinks & & \\
\hline & Yes & 377 & 94.25 \\
\hline & No & 23 & 5.75 \\
\hline
\end{tabular}


health conditions which could be gastrointestinal, reproductive or neurological in nature, in all age groups including young adults. Whether private or public water source, water quality should be maintained to avoid outbreak and spread of disease such as diarrhea and dysentery which are most common in this part of the country.

Also most of the respondents 272(69) agreed to drinking rain water during rainy season while 128 (31) of the respondents claim they don't drink rain water but use it for house hold chores. From this, the tendencies of this water being polluted at the point of collection is eminent especially when collected under corrugated iron roofing sheets, aluminum roofing sheets or asbestos as the case may be, and this could be hazardous to the health of the individuals. According to researches by, [34] it is worthy of note that only $16 \%$ of the entire population in Sub Saharan Africa (SSA) have access to safe and adequate water supply through improved pipe system. In a separate analysis, research by [35], which delved into "the effects of roofing materials on harvested rain water", showed in his analysis that $\mathrm{P}^{\mathrm{H}}$ values for the harvested rain water was acidic to a small extent, though this could be area specific, but may have an indirect effect on human health [36]. His work also found that the phosphorus contents for the harvested rain water exceeded the WHO tolerable limits of $0.3 \mathrm{mg} / \mathrm{l}$ hence making the water unsafe for drinking. The iron contents of water collected under corrugated iron roofing sheet and asbestos roofing sheet exceeded WHO acceptable limits of $0.3 \mathrm{mg} / \mathrm{l}$ as well. His work also showed that there were traces of lead in the harvested rain water exceeding WHO tolerable limits of $0.001 \mathrm{mg} / \mathrm{l}$ also making the water unsafe for drinking especially for infants and pregnant women. According to his analysis metal roofing sheets do not always leach heavy metals in high concentrations as compared to asbestos roofing material [36].

On their most common drinking water source, most of the respondents 200(50) chose pure sachet water, only 93(23.25) drank bottle water as their major source of drinking water but resort to drinking pure water when they are low on cash. A handful 53(13.25) of the respondents drank well water, 40(10) of the respondents drank borehole water, while 13(3.25) of the respondent drank plain tap water, and only $1(0.25)$ of the respondent drank water from stream. Going by the socio-economic levels of the respondents, it's not surprising the about half of them drink pure sachet water regularly, even though it is categorized as improved water by [37], also people consider pure water as a convenient source of safe water for drinking, and its easy availability enhances its use.

On the approximate quantity of water consumed per day, mean values, shows that about 200(50) of the respondents drink between $50 \mathrm{CL}-1.5 \mathrm{~L} /$ day of water 107(26.75) of the respondents drink $2 \mathrm{~L}-3 \mathrm{~L} /$ day of water, $80(20)$ of the respondent drink between $3.5 \mathrm{~L}-4.5 \mathrm{~L} /$ day of water, while only 13(3.25) of the respondent drink between $5-61 /$ day of water. None of the respondents drank between $6.5 \mathrm{~L}-7.5 \mathrm{~L} /$ day of water. Based on this data, it is quite obvious that about half of the respondents drink less than $1.5 \mathrm{~L}$ of water daily. This is by far below the mean recommended quantity for both male or female, which are 3.2 
L/day according to Institute of Medicine [6], more recent recommendation from the European Food Safety Authority [7] also shows that majority of the respondents sampled drink less than the mean of total water intake per day which is $2.25 \mathrm{~L} /$ day. This has the tendency of affecting thermoregulation in those individual affected, physical performance cognition especially in young adults aged between 18 years - 25 years, it can also be an open door to delirium, which paves way to early dementia [37], it can also affect kidney, heart, and head function, as well as the skin appearance. The few respondents who drank between $5 \mathrm{~L}-6$ L/day of water could be attributed to either alcohol, diabetes or both, based on the results obtained in this work, as research has established it that alcohol increases water excretion hence increasing the demand for a high consumption. Diabetes increases thirst which promotes high water consumption.

When asked of their most commonly consumed fruit types, most of the respondents 174(43.5) said they take oranges as their most common fruit type this basically is also a reflection of their socio-economic levels (SELs), even though its contribution to the total fluid intake (TFI) per day, will depend on the quantity, specie/type of orange, and the season, while 160(40) of the respondents eat apple. One orange and one apple contain approximately $87 \%$ water respectively. Some of the respondents $80(20)$ eat water melon regularly, water melon is made up of $92 \%$ water and contributes highly to the daily total fluid intake, and should be encourage. Few of the respondents 53(13.25) claim they eat mangoes and bananas respectively. as their most commonly consumed fruits, these contributes not as much fluid to the total fluid intake per day, as compared to oranges and water melon noting with respect to other nutrient contents that they are also healthy. Orange was the fruit that contribute frequently to their total body fluid.

Of all the respondents, 40(10) attested to being diabetic and are likely to fall within the group that drink $6-7 \mathrm{~L}$ /day of water due to high thirst a major characteristic of the disease, while 360(90) of the respondents were not.

On alcohol consumption, 13(3.25) of the respondents who were mostly male said they consume alcohol, while 387(96) of the participant do not drink alcohol.

\section{Conclusions}

From the study, the average daily drinking water consumed by young adults in Mubi Adamawa State, was between 50 L - 1.5 Liters of water with a vast majority of these young adults taking orange as the most common and affordable fruit that contributed to their daily total body fluid intake apart from carbonated drinks. Most of the students had a spending power of less than $10.000 /$ month, as a result pure sachet water popularly known as "pure water" was their most common drinking water source.

Finally, 377(94.25) of the respondents confirmed to the fact that they drink carbonated drink almost on a daily basis, this could reduce plain drinking water consumption. Nutritionally this is harmful to the health of the young adults, as these drinks are very high in refined sugar and could have dare consequences in the future. 


\section{Recommendation}

1) Public enlightenments should start on the need to drink more water especially among the young adults.

2) Interventions are required to improve the drinking water consumption pattern among young adults.

3) Every community should make available clean, portable water which should be safe for drinking, to improve the water consumption pattern of young adults in the community.

\section{Conflicts of Interest}

The authors declare no conflicts of interest regarding the publication of this paper.

\section{References}

[1] Widerström, M., Schönning, C., Lilja, M., Lebbad, M. and Ljung, T. (2014) Large Outbreak of Cryptosporidium hominis Infection Transmitted through the Public Water Supply, Sweden. Emerging Infectious Diseases, 20, 581-589. https://doi.org/10.3201/eid2004.121415

[2] Laine, J., Huovinen, E., Virtanen, M.J., Snellman, M., Lumio, J., Ruutu, P., et al. (2011) An Extensive Gastroenteritis Outbreak after Drinking-Water Contamination by Sewage Effluent, Finland. Epidemiology and Infection, 139, 1105-1113. https://doi.org/10.1017/S0950268810002141

[3] Jequier, E. and Constant, F. (2010) Water as an Essential Nutrient: The Physiological Basis of Hydration. European Journal of Clinical Nutrition, 64, 115-123. https://doi.org/10.1038/ejcn.2009.111

[4] Lang, F. (2011) Effect of Cell Hydration on Metabolism. Sports Nutrition: More than Just Calories-Triggers for Adaptation, Nestlé Nutrition Institute Workshop Series, Vol. 69, 115-130. https://doi.org/10.1159/000329290

[5] Benelam, B. and Wyness, L. (2010) Hydration and Health: A Review. Nutrition Bulletin, 35, 3-25. https://doi.org/10.1111/j.1467-3010.2009.01795.x

[6] IOM (Institute of Medicine) (2005) Panel on Dietary Reference Intakes for Electrolytes and Water, Dietary Reference Intakes for Water, Potassium, Sodium, Chloride and Sulfate. Food and Nutrition Board. The National Academies Press, Washington DC. http://www.nap.edu/openbook.php?isbn=0309091691

[7] European Food Safety Authority (EFSA), Parma, Italy (2010) EFSA Panel on Dietetic Products, Nutrition and Allergies. Scientific Opinion on Dietary Reference Values for Water. EFSA Journal, 8, 1459.

[8] Morin, C., Gandy, J., Brazeilles, R., Moreno, L.A., Kavouras, S.A., Martinez, H., Salas-Salvadó, J. and Bottin, J. (2018) Isabelle Guelinckx Fluid Intake Patterns of Children and Adolescents: Results of Six Liq.In ${ }^{7}$ National Cross-Sectional Surveys. European Journal of Nutrition, 57, S113-S123. https://doi.org/10.1007/s00394-018-1725-y

[9] Guelinckx, I., Iglesia, I., Bottin, J.H., De Miguel-Etayo, P., Gonzalez-Gil, E.M., Salas-Salvado, J., Kavouras, S.A., Gandy, J., Martinez, H., Bardosono, S., Abdollahi, M., Nasseri, E., Jarosz, A., Ma, G., Carmuega, E., Thiebaut, I. and Moreno, L.A. (2015) Intake of Water and Beverages of Children and Adolescents in 13 Countries. European Journal of Nutrition, 54, 69-79. https://doi.org/10.1007/s00394-015-0955-5 
[10] Gandy, J., Martinez, H., Carmuega, E., Arredondo, J.L., Pimmental, C., Moreno, L.A., Kavouras, S.A., Salas-Salvadó, J. and Guelinckx, I. (2018) Fluid Intake of Latin American Children and Adolescents: Results of Four 2016 Liq. In $^{7}$ National Cross-Sectional Surveys. European Journal of Nutrition, 57, 53-63. https://doi.org/10.1007/s00394-018-1724-Z

[11] Moynihan, P.J. and Kelly, S.A. (2014) Effect on Caries of Restricting Sugars Intake: Systematic Review to Inform WHO Guidelines. Journal of Dental Research, 93, 8-18. https://doi.org/10.1177/0022034513508954

[12] Katzmarzyk, P.T., Broyles, S.T., Champagne, C.M., Chaput, J.P., Fogelholm, M., Hu, G., Kuriyan, R., Kurpad, A., Lambert, E.V., Maia, J., Matsudo, V., Olds, T., Onywera, V., Sarmiento, O.L., Standage, M., Tremblay, M.S., Tudor-Locke, C. and Zhao, P. (2016) Relationship between Soft Drink Consumption and Obesity in 9-11 Years Old Children in a Multi-National Study. Nutrients, 8, 770.

https://doi.org/10.3390/nu8120770

[13] Institute of Medicine, Food and Nutrition Board (2004) Dietary Reference Intakes for Water, Potassium, Sodium, Chloride and Sulfate. National Academies Press, Washington DC.

https://www.nap.edu/catalog/10925/dietary-reference-intakes-for-waterpotassium-s odium-chloride-and-sulfate

[14] Kavouras, S.A., Johnson, E.C., Bougatsas, D., Arnaoutis, G., Panagiotakos, D.B., Perrier, E. and Klein, A. (2015) Validation of the Urine Color Scale in Children. European Journal of Nutrition, 55, 907-915. https://doi.org/10.1007/s00394-015-0905-2

[15] Sanchez-Romero, L.M., Penko, J., Coxson, P.G., Fernandez, A., Mason, A., Moran, A.E., Avila-Burgos, L., Odden, M., Barquera, S. and Bibbins Domingo, K. (2016) Projected Impact of Mexico's Sugar-Sweetened Beverage Tax Policy on Diabetes and Cardiovascular Disease: A Modeling Study. PLOS Medicine, 13, e1002158. https://doi.org/10.1371/journal.pmed.1002158

[16] Paraje, G. (2016) The Effect of Price and Socio-Economic Level on the Consumption of Sugar-Sweetened Beverages (SSB): The Case of Ecuador. PLoS ONE, 11, e0152260. https://doi.org/10.1371/journal.pone.0152260

[17] Wang, T.Z.Q., Pan, H., Gan, Q., Li, L., Yang, T., Xing, Q. and Hu, X. (2016) Food Intake of Students from Nutrition Improvement Programme for Rural Compulsory Education Students in 2013. Chinese Journal of School Health, 37, 670-673.

[18] Dairy Association of China (2017) White Paper of Chinese Dairy Industry: School Milk Program Has Benefited More than 20 Million Primary and Middle School Students. Anim Husb Xinjiang 7, 62.

[19] Puwita, W.L., Clementina, M., Joan, G., Luis, A.M. and Isabella, G. (2018) Fluid Intake of Children Adolescents and Adults; a National Cross Sectional Survey. European Journal of Nutrition, 57, 89-100.

[20] WHO/UNICEF Progress on Drinking Water (2017) Sanitation and Hygiene. http://www.who.int/water sanitation health/publications/jmp-2017/en

[21] Kementerian Kesehatan, R.I. (2014) Pedoman Gizi Seimbang.

[22] Ng, M., Fleming, T., Robinson, M., Thomson, B., Graetz, N., Margono, C., et al. (2014) Global, Regional, and National Prevalence of Over-Weight and Obesity in Children and Adults during 1980-2013: A Systematic Analysis for the Global Burden of Disease Study 2013. The Lancet, 384, 766-781. https://doi.org/10.1016/S0140-6736(14)60460-8

[23] Prevalence of Diabetes in the WHO South-East Asia Region (2017). 
[24] Piernas, C., Ng, S.W., Mendez, M.A., Gordon-Larsen, P. and Popkin, B.M. (2015) A Dynamic Panel Model of the Associations of Sweetened Beverage Purchases with Dietary Quality and Food-Purchasing Patterns. American Journal of Epidemiology, 181, 661-671. https://doi.org/10.1093/aje/kwu317

[25] Danyliw, A.D., Vatanparast, H., Nikpartow, N. and Whiting, S.J. (2011) Beverage Intake Patterns of Canadian Children and Adolescents. Public Health Nutrition, 14, 1961-1969. https://doi.org/10.1017/S1368980011001091

[26] Adebayo, A.A. (2004) Mubi Region; a Geographical Synthesis. Paraclates Publishers, Yola, 32-38.

[27] National Population Commission Census in Nigeria 2006.

[28] Hedrick, V.E. (2010) The Beverage Intake Questionnaire: Determining Initial Validity and Reliability. Journal of American Dietetic Association, 110, 1227-1232. https://doi.org/10.1016/j.jada.2010.05.005

[29] Adebambo, A.V. (2010) The Cultural Influence on Child Marriage, Focus on Northern Nigerians Resident in Ogun State, Nigeria. Thesis Home Science and Management College of Food Science and Human Ecology, University of Agriculture, Abeokuta.

[30] National Population Commission International Research Center for Research on Women (ICRW). How to End Child Marriage: Action Strategies for Prevention and Protection. Washington DC.

[31] Allen, A.A. and Adekola, P.O. (2017) Health Implication of Child Marriage in North-East Nigeria. Analele Universităţiidin Oradea, Seria Geografie, 27, 54-61.

[32] Mayer, S.E. (2002) Influence of Parental Income on Children's Outcome. Knowledge Management Group, Ministry of Social Development, Wellington.

[33] Center for Disease Control and Prevention, Water Diseases and Contaminants (2010).

[34] WHO (2011) Guidelines for Drinking Water Quality. 4th Edition, WHO Press, Geneva, $541 \mathrm{p}$.

[35] Ojo, O.M. (2019) Effects of Roofing Materials on Harvested Rain Water Quality. Journal of Applied Sciences and Environmental Management, 23, 735-738. https://doi.org/10.4314/jasem.v23i4.25

[36] WHO/UNICEF (2012) Joint Monitoring Programme (JMP) for Water Supply and Sanitation. WHO Press, Geneva.

[37] Popkin, B.M., D’Anci, K.E. and Rosenberg, I.H. (2012) Water, Hydration, and Health. Nutrition Reviews, 68, 439-458. https://doi.org/10.1111/j.1753-4887.2010.00304.x 